\title{
Developing Learning Trajectory Based Instruction of the Congruence for Ninth Grade Using Central Java Historical Building
}

\author{
Achmad Fahrurozi ${ }^{1)}$, Suci Maesaroh ${ }^{1)}$, Imam Suwanto ${ }^{1)}$, Farida Nursyahidah ${ }^{1)}$ \\ 1) Department of Mathematics Education, Universitas PGRI Semarang \\ Corresponding author:: faridanursyabidah@upgris.ac.id
}

\begin{abstract}
This research aims to produce a Learning Trajectory Based Instruction (LTBI) that can belp the ninth grade students understand the concept of congruence of the two-dimensional shape by examining Lawang Sewu as one of Central Java historical buildings. LTBI is defined as a teaching and learning trajectory that uses Hypothetical Learning Trajectory (HLT) for instructional decisions. The present research uses the design research developed by Gravemeijer and Cobb that consists of three phases; the preliminary design, design of the experiment (pilot experiment and teaching experiment), and retrospective analysis. In this study, a series of learning activities is designed and developed based on the Realistic Mathematics Education (PMRI) approach. This research produced LTBI that consists of a series of learning processes embodied in three activities of (1) identifying and finding the properties which shapes are congruent shapes by watching Lawang Sewu video, (2) proofing two shapes are congruent through transformation (translation and rotation), and (3) solving problem related to the congruence of two-dimensional shape. The activity can help to improve the students' understanding of the concept of congruence. Nevertheless, the present study is limited to the first stage of Gravemeijer and Cobb's design research, namely preliminary design.
\end{abstract}

Keywords: Hypothetical Learning Trajectory, Lawang Sewu, PMRI, Congruence

\section{Introduction}

Geometry is an important material in learning because: (1) it helps humans have an appreciation toward the whole of the world, (2) exploration of geometry can help to develop problem solving skills, (3) it plays a major role in other fields of mathematics, (4) it is useful in daily life, and (5) it is enigmatic and enjoyable (Walle, 1994: p. 35). Nevertheless, geometry is often regarded as a difficult, boring, even scary lesson, especially related to material of congruence. Chi in Panjaitan (2013) confirmed that the problem faced by students is to understand the concept of congruence such as student's lack of understanding of the differences between congruence and similarity of twodimensional shape, student's difficulties to understand that the similarity of triangle is applicable to all types of triangle. Students often experience difficulties in understanding sides and angles. They hardly distinguish that two-dimensional shape and triangle may be similar but not necessarily congruent, while these are congruent must be similar. In addition, Kurniati (2010) stated that in solving congruence and similarity problems, most students make errors due to their lack of understanding on the concept, particularly on the concept of congruence (50\%).

The perplexity experienced by students is influenced by several factors, one of which is a teacher-centered learning. Marpaung (2009) claimed that the teacher-centered 
learning leads to students' passiveness and high reliability on teachers. Students tend to memorize concepts without understanding the meaning. Such kind of learning potentially leads to low outcome of student learning. In addition, according to Zulkardi (2002), the low outcome of learning mathematics is caused by several factors, namely: (1) a solid curriculum, (2) complicated and unattainable materials in the textbook, (3) noninteractive conventional learning method, (4) less effective learning process, (5) ineffective evaluation. Therefore, it is necessary to resolve the problem by designing learning trajectory based instruction by choosing the appropriate learning approach by employing familiar context for students as well as the use of interactive media. One of the approaches that can be used by using a proper context is Realistic Mathematics Education or PMRI.

PMRI is popular among mathematics teachers to develop the students' ability of thinking, reasoning, communicating and solving problems both in the class and daily life (Zulkardi, 2002). This approach has been used since 2001 and widely used as an effort to improve the students' interest and attitude as well as their study outcome (Prahmana, 2012; Muttaqin, 2017; Nursyahidah, 2013, 2014, 2018; and Saputro, 2014). Furthermore, there are five main characteristics of RME (Gravemeijer, 1994; Akker, 2006), namely: (1) phenomenological exploration; (2) bridges with vertical instrument; (2) the contributions of students; (3) interactivity; and (4) intertwinement. In addition, this approach can create effective, efficient and fun learning so that the learning goals like problem solving ability can be achieved (Nursyahidah, 2018). The principle of this approach is on the activities of the visualization of concrete objects, or the use of the context around the students advance to the most abstract level. The contextual approach in the process of learning can help students understand the concepts quickly and easily. In learning mathematics, the approaches can be in the form of traditional games (Prahmana, 2012; Nursyahidah, 2013, 2014; and Jaelani, 2013), folktales and legends (Triyani, 2012; Lestariningsih, 2012; and Widyawati, 2016), and formal mathematical forms (Puspasari, 2015). In the present study, Lawang Sewu, a local historical building of Semarang, Central Java, Indonesia, is selected to apply the PMRI approach in learning congruence. Besides, this building has many shapes that can represent congruence concept, it also has already known among students in Semarang. In addition, it is relative new and has not been explored by mathematics teachers hence hopefully this context can help students understand the concept of congruence.

Simon (1995) introduced the term of Hypothetical Learning Trajectory (HLT) to represent the learning process of students' prior knowledge to learning objectives set by the teacher. Marpaung (2009) stated that there are three components in HLT: (1) learning objectives, (2) learning activities, and (3) thinking and learning method of students. In addition, Marpaung (2009) mentioned the trajectory as a learning pathway because it reveals the student's hypothetical path. According to Romber and Carpenter in Nursyahidah (2013), learning and teaching are regarded as two sides of the same coin, yet they are often disconnected in some studies. One of the efforts to link them was conducted by Sztajn (2012). It combined learning and teaching to build what is referred to as the Learning Trajectory Based Instruction (LTBI). A trajectory defined as LTBI in teaching and learning is used for instructional decision of HLT (Sztajn, 2012).

The philosophy of Realistic Mathematics Education (RME) is mathematics as a human activity. It means that learning mathematics should trigger students to recognize that there is mathematics in human activity, hence it is useful in real life (Julie, 2016). Therefore, the process of learning mathematics should not be initiated by mathematics as a deductive system - which is well organized and formal - but mathematics as a human activity (Freudenthal in Gravemeijer (1994). If mathematics is connected to a formal 
deductive system, students will only see the concept of mathematics, which is abstract, instead of using mathematics in the real life (Prahmana, 2012).

Based on the background, the problem in this study is how to develop learning trajectory based instruction of the congruence for ninth grade using central java historical building? Moreover, the aim of this study is to develop learning trajectory based instruction of the congruence for ninth grade using central java historical building.

\section{Research Methods}

The research methodology used in this study is the design research developed by Gravemeijer and Cobb in Akker (2006). There are three phases in the design research, namely the preliminary design, the design experiment, and the retrospective analysis. The first step is preliminary design. The main purpose of this first step is to make hypotetical learning trajectory (HLT) and design instruments to improve the learning process. The second step is the design experiments. In this second phase, researchers try the learning activities designed in the first stage. This trial aims to explore the actual learning strategies and processes. At this stage several things are done as follows: (1) pilot experiments, i.e. HLT testing that has been designed in small groups involving students with high, intermediate, and low ability of 2 children each; (2) teaching experiments, ie testing HLTs that have been designed, tested in small groups, and refining the class that is the subject of research. The third step is the retrospective analysis. Some steps that will be taken at this stage include: (1) analyzing the data that has been obtained from the teaching experiment stage and the results of the analysis are used to organize activities and develop activities in later learning, (2) comparing HLT with actual student learning, answering the formulation problem. In addition, the subject of this study is the third grade lower secondary school students at one of junior public schools in Semarang, Central Java. This study was conducted on May to June 2018.

The present study will explain the result of the first phase of the design research. In this phase, the researchers conducted the following activities:

1. Assessing the basic competencies that are already owned by the students before the students learn the congruence based on the 2013 curriculum.

2. Reviewing the basic competencies required by the students to learn the congruence based on the 2013 curriculum.

3. Developing the LTBI of congruence based on PMRI approach and Lawang Sewn context.

\section{Results and Discussion \\ Assessing the basic competencies that are already owned by the students}

The assessment on the prior basic competencies of students showed that the students have learnt about congruence based on the 2013 curriculum. The results are as follows:

The prior basic competence that are already owned by students in the first grade namely: comparing two numbers up to two digits numbers by using concrete objects, recognizing three-dimensional shape and two-dimensional shape by using various concrete objects, identifying two-dimensional shape that can be arranged to form a pattern, ordering numbers up to two digits numbers from the smallest to the largest integer number or vice versa by using concrete objects, classifying two-dimensional shape and three-dimensional shape based on certain properties using various concrete objects, arranging the two-dimensional shape to form a pattern.

Next, the prior basic competence that are already owned by students in the second grade namely: describing a line segment by using concrete models of two-dimensional 
shape and three-dimensional shape, describing two-dimensional shape and threedimensional shape based on their characteristics, identifying a line segment by using concrete models of two-dimensional shape and three-dimensional shape, classifying twodimensional shape and three-dimensional shape based on their characteristics.

Then, the prior basic competence that are already owned by students in the third grade namely: explaining folding symmetry and rotating symmetry on two-dimensional shape by using concrete objects, explaining angle, types of angles (right angle, the angle of the taper, and blunt angle), and unit of non-standard measurement, analyzing a variety of two-dimensional shape based on their properties, identifying the folding symmetry and rotating symmetry on two-dimensional shape by using concrete objects, identifying the type of angle, (right angle, acute angle, and obtuse angle) and non-standard unit, classifying different two-dimensional shapes based on their properties.

In addition, the prior basic competence that are already owned by students in the fourth grade namely: analyzing the properties of regular polygon and irregular polygon, explaining the relationship between the lines (parallel, intersect, and coincide) by using concrete models, explaining and determining the measure of the angle in the twodimensional shape in standard unit using a protractor, identifying regular polygon and irregular polygon, measuring the angle on two-dimensional shape in standard unit using a protractor.

\section{Reviewing the basic competencies required by the students}

Furthermore, the reviewing basic competencies that students needed to have associated with the congruence based on the 2013 revision curriculum is in the fifth grade and the sixth grade. Those can be explained are as follows.

For the fifth grade, there are some basic competencies that students need to deal with, namely (1) explaining the proportion of two different quantities (speed or distance: time and discharge or volume, time, (2) solving problems related to the comparison of two different quantities (speed and discharge). Furthermore, there are some basic competencies that students need to have in the sixth grade, namely: (1) distinguishing the direct proportion and inverse proportion using data tables, graphs, and equations, (2) analyzing the relationship between angles as a result of two parallel lines cut by a transversal line, (3) associating the formula of perimeter and area of any types of quadrilateral (square, rectangle, rhombus, parallelogram, trapezoid, and kite) and triangle, (4) solving problems related to the direct proportion and inverse proportion, (5) solving problems related to the relationship between the angle as a result of two parallel lines cut by a transversal line, (6) solving contextual problems related to area and perimeter of the quadrilateral (square, rectangle, rhombus, parallelogram, trapezoid, kite, and triangle.

\section{Developing Learning Trajectory Based Instructions (LTBI)}

The first step in developing LTBI is determine indicators of teaching and learning process in congruence, namely: a) Students can identify two objects are congruent or not through discussion and debriefing, b) Students can find two shapes that are congruent through discussion and questioning, c) Students can find two shapes that are congruent with translation through discussion and questioning, d) Students can find two shapes that are congruent with rotation through discussion and questioning.

The next step is arranging activities for teachers and students that can be explained as follows:

a) Activities to build social norms or rules in class

The teacher conveys the social norms or rules that will be applied in the classroom, including: (1) When students want to express their opinions, ask 
questions, answer questions, or provide feedback to the opinions of others, they should lift their hands and be allowed by the teacher before speaking up, (2) when there is student who expresses an opinion, other students will pay attention for her/him, (3) if the teacher asks students about their answers, it does not mean that the answer must be incorrect, but the teacher wants to know the student's way of thinking.

b) Exploration problem

There are some activities in exploration problem step, which are (1) Students watch a video of Lawang Sewu which contains the material of congruence. In the video, students can see the complete appearence of Lawang Sewu not only the appearance of outside of this building, for instance from the front side, left and right side, but also the appearance of inside of this building. The students can see many things there and they assisted by the audio that can help them to know it. After watching that video the students should identify any two-dimensional shape in the building of Lawang Sewu that have the similar form and size. By observing the Lawang Sewu video, students will be able to mention some two-dimensional shapes that have the similar form and size, such as the shape of the doors and windows is rectangle, the shape of the roof is trapezoid, the shape of roof and garden is triangle, and the shape of some pictures is square. However, there is a possibility for students who only recognize one or two parts of Lawang Sewu, which is the rectangular shape of door, (2) Students are given the following problem: Draw the parts of Lawang Sewu which have two-dimensional shape. It is an effort to bring up the characteristics of phenomenological exploration in PMRI, (3) teacher helped students in depicting a wide variety of two-dimensional shape and triangle, the teacher can guide the students to observe the existing sections of Lawang Sewu hence they will notice the forms of two-dimensional shape and triangle. It is an effort to bridge the characteristics of vertical instruments in PMRI, (4) the students are given time to discuss with a peer. It is an effort to promote the characteristics of interactivity in PMRI.

c) Class discussion

In this step, students will do some following activities. The first, one student is requested to explain the strategy used to determine the form of two-dimensional shape and triangle in the Kolase video to other students. There are three possible methods used by students, namely: (a) students watched a Kolase video and identified the objects in Lawang Sewu that have two-dimensional shape, (b) students watched a Kolase video in which they will be able to identify three-dimensional shape and find two-dimensional shape that constructs three dimensional shapes, (c) students watched a Kolase video in which they will be able to identify the two-dimensional shape but have not been able to mention the name of two-dimensional shape that forms three-dimensional shape. Each process made by students to solve the problems in the RME is referred to as the model. It is an attempt to raise the characteristics of RME that are contributed to the students. Next, Other students are inquired to respond to what is presented by other groups. Next, The teacher asks another student who has a different strategy to convey the concept. Then, Other students are inquired to respond to what is conveyed by the students. The last, teacher conducts discussion and guide students to identify two-dimensional shapes that are congruent from the Lawang Sewu video (in mathematics).

d) Exploration problem

There are some activities in this exploration step. The first, students are asked to prove the congruence of two-dimensional shapes by transformation, namely 
translation and rotation. To prove that, students are given an origami paper provided by the teacher. They are asked to give a name at the vertex of origami paper with the name $A B C D$ and PQRS, then slide the rectangle $A B C D$ on the paper so that point $A$ is coincide to point P. Students will be able to describe that PQRS square covers $\mathrm{ABCD}$ square by translating and rotating, because the sides of the $\mathrm{ABCD}$ square corresponding to the sides of PQRS square. In addition, they have similar form and similar size of the angle. Furthermore, the form of origami paper can be shown in Figure 1.

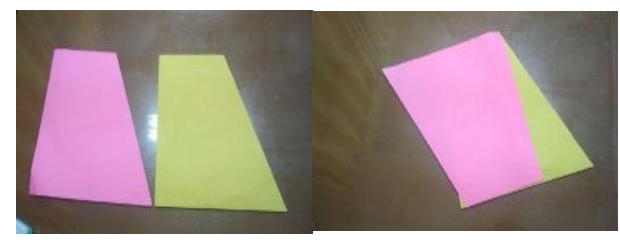

Figure 1. Origami paper as a media

In this activity consist of some step, namely (a) students are given the following problem: estimate "Does ABCD square cover PQRS square perfectly? How do you find out?" It is an attempt to bring up the characteristics of phenomenological exploration in PMRI, (b) teacher assists students in clarifying the ABCD square that covers PQRS square perfectly. Subsequently, teacher gives questions to students to reinvent the concept of two-dimensional shape which includes parts of twodimensional shape in order to show the characteristics of vertical instrument in PMRI, (c) students are given time to discuss with a peer. It is an effort to produce the characteristics of interactivity in PMRI. Each process done by students as the problem solving in the PMRI is referred to as the model. It is an effort to raise the characteristic of PMRI, namely the contribution of the students.

The second activity is other students are asked to respond to what is presented by the presenters. Next, the teacher asks other students who have different strategies to explain their ideas. Then, other students are asked to respond to what is presented by the students. The last, teacher conducts discussion and guide students to notice the properties of congruence by transformation (translation and rotation).

e) Exploration problem

There are some activityes in this exploration problem. The first, students are given the following problem: "Are two-dimensional shapes that are congruent certainly similar? And is every similar two-dimensional shape certainly congruent? To what extent can you explain that question?" It is an effort to bring up the characteristics of phenomenological exploration in PMRI. Next, teacher helps students to find whether two congruent shapes are definitely similar and whether similar two-dimensional shapes are certainly congruent. Teacher can discuss the previous material. It is an attempt to bridge the characteristics of vertical instruments in PMRI. In addition, students are given time to discuss with a peer. It is an attempt to reproduce the characteristics of interactivity in PMRI.

f) Class discussion

In this class discussion step, there some activities that will be done by the students. The first is a student is requested to explain about what his/her strategy to determine the solution. There are two possible methods used by students, namely: (a) the students recall what has been already done before. Another alternative, students could determine that the two shapes which are congruent must have the same form and size, and (b) students attempt to make a model of two-dimensional shape with 
the same form and size to answer those problems. Each process done by students to solve the problem in the PMRI is referred to as the model. It is an effort to stimulate one of the characteristics of PMRI, namely the contribution of the students.

The next step is other students are asked to respond to what is presented by the student. Then, the teacher asks another student who has a different strategy to present his/her ideas. Moreover, other students are asked to respond to what is presented by the student. The last, teacher conducts class discussion and guides students to find out the concept of the properties of congruence.

Based on the result, the students' understanding of congruence can be supported by LTBI designed. The students' understanding can be developed from informal to the formal level. Students can reinvent concept of congruence from the Lawang Sewu video provided by the teacher as a context which is already well known among students. This is in agreement with the Hans Freudenthal's views of RME, namely: "mathematics must be connected to reality". Learning congruence by using historical building as a context and PMRI approach can stimulate students' understanding about topic concept learned. This is in line with Zulkardi (2002) stated that using context as a starting point in learning process can help students understanding the concept learned from informal level to formal level. Moreover, this LTBI also suitable with the result of sevaral studies stated that the use of appropriate context for learning give a positive influence on learning mathematics that more meaningful, fun, and it can improve students' understanding of mathematical concepts learned (Nursyahidah, 2013; Prahmana, 2012).

\section{Conclusion}

The findings of this study show the development of hypotetical learning trajectory based instruction (LTBI) of the congruence for ninth grade using central java historical building consists of a series of learning processes embodied in three activities namely (1) watching lawang sew $u$ video to identify and find the similar shape and size of twodimensional shapes, (2) proofing two shapes that are congruent through transformation (translation and rotation) using origami paper, and (3) solving problem related to the congruence of two-dimensional shape.

\section{Acknowledgement}

The researchers would like to express their gratitude to the Ministry of Research, Technology and Higher Education, the Republic of Indonesia that has provided the Student Creativity Program Grant in 2018. Furthermore, the researchers would like to thank Universitas PGRI Semarang for the opportunity to present and publish the research report.

\section{Bibliography}

Akker, J. V. D., Gravemeijer, K., McKenney, S., \& Nieveen, N. (2006). Educational Design Research. New York: Taylor and Francis Group.

Gravemeijer, K. P. G. (1994). Developing Realistic Mathematics Education. Utrecht: Freudenthal Institute.

Jaelani, A., Putri, R. I. I., \& Hartono Y. (2013). Students' Strategies of Measuring Time Using Traditional Gasing Game in Third Grade of Primary School. IndoMS. J.M.E., 4(1), p. 29-40.

Julie, H. (2016). Developing Student Learning Materials on Multiplication Fraction for Grade Five with Realistic Mathematics Education. In Proceedings of the 4th SEADR Conference, Padang. 
Kurniati. (2010). Analisis Tingkat Ketuntasan Belajar Siswa dalam Pokok Bahasan Kesebangunan dan Kekongruenan melalui Pendekatan Kooperatif. Tesis. Bandung: UPI

Lestariningsih, Putri, R. I. I., \& Darmawijoyo. (2012). The Legend of Kemaro Island for Supporting Students in Learning Average. IndoMS. J.M.E., 3(2), p. 165-174.

Marpaung, Y. (2009). PMRI Merupakan Pendekatan Pembelajaran Matematika yang Memberdayakan Siswa. Paper presented in Seminar of Festival Sains III organized by Sekolah Kristen Kalam Kudus Surakarta.

Muttaqin, H., Putri, R. I. I., \& Somakim. (2017). Design Research on Ratio and Proportion Learning by Using Ratio Table and Graph with Oku Timur Context at the $7^{\text {th }}$ Grade. IndoMS. J.M.E., 8(2), p. 211-222.

Nursyahidah, F., Putri, R. I. I., \& Somakim. (2013). Supporting First Grade Students' Understanding of Addition up to 20 Using Traditional Game. IndoMS.J.M.E., 4(2), p. 212-223.

Nursyahidah, F., Putri, R. I. I., \& Somakim. (2014). Instructional Design of Subtraction using PMRI Approach Based on Traditional Game. Proceedings of the $2^{\text {nd }}$ SEA-DR Conference, Palembang.

Nursyahidah, F., Saputro B. A., \& Rubowo, M.R. (2018). Supporting second grade lower secondary school students' understanding of linear equation system in two variables using ethnomathematics. IOP Conf. Ser.: Inter. Cof. On Math., Sci, and Edu, 983012119.

Nursyahidah, F., Saputro, B. A., \& Rubowo, M. R. (2018). A Secondary Student's Problem Solving Ability in Learning Based on Realistic Mathematics with Ethnomathematics. JRAMathEdu, 3(1), p. 13-24.

Panjaitan, S M. (2013). Pembelajaran Matematika Beraliran Humanistik Berparadigma Pendekatan Kontekstual. Retrieved from http://vitonasya.blogspot.com/2013 L11/pembelajaran-matematika-beraliran.html [Accessed on 23-2- 2014].

Prahmana, R. C. I., Zulkardi, \& Hartono, Y. (2012). Learning Multiplication Using Indonesian Traditional game in Third Grade. IndoMS. J.M.E, 3(2), p. 115-132.

Puspasari, L., Zulkardi, \& Somakim. (2015). Desain Pembelajaran Luas Segi Banyak Menggunakan Tangram Berpetak di Kelas IV. JINoP. 1(2), p. 150-162.

Saputro, B. A., Prayito, M., \& Nursyahidah, F. (2015). Media Pembelajaran Geometri Menggunakan Pendekatan Pendidikan Matematika Realistik Berbasis GeoGebra. Kreano, 6(1), p. 33-38.

Simon, M. A. (1995). Reconstructing Mathematics Pedagogy from a Constructivist Perspective. Journal of Research in Mathematics Education, 26, p. 114-145.

Sztajn, P. Confrey J., Wilson, P. H., \& Edgington, C. (2012). Learning Trajectory based Instruction: Toward a Theory of Teaching. Educational Researcher, 41(5), p. 147156.

Triyani, S., Putri, R. I. I., \& Darmawijoyo. (2012). Supporting Student's Ability in Understanding Least Common Multiple (LCM) Concept Using Storytelling. IndoMS. J.M.E, 3(2), p. 151-164.

Van de Walle, J. A. (1994). Elementary School Mathematics. New York: Longman.

Widyawati,W., Putri, R.I.I., \& Somakim. (2016). Desain Pembelajaran Sudut Menggunakan Konteks Rumah Limas di Kelas VII. JINOP, 2(2), p. 437-448.

Zulkardi. (2002). Developing a Learning Environment on Realistic Mathematics Education for Indonesian Student Teachers. Thesis. University of Twente. The Netherlands: PrinPartners Ipskamp-Enschede. Retrieved from http://doc.utwente.nl/58718 $\angle 1 /$ thesis Zulkardi.pdf. 